Int. J. Morphol.,

34(3):848-853, 2016

\title{
An Osteometric Evaluation of the Mandibular Condyle in a Black KwaZulu-Natal Population
}

\author{
Una Evaluación Osteometrica del Cóndilo Mandibular en una Población Negra KwaZulu-Natal
}

\author{
S. Ishwarkumar*; P. Pillay*; B. Z. DeGama* \& K. S. Satyapal
}

ISHWARKUMAR, S.; PILLAY, P.; DEGAMA, B. Z. \& SATYAPAL, K. S. An osteometric evaluation of the mandibular condyle in a black KwaZulu-Natal population. Int. J. Morphol., 34(3):848-853, 2016.

SUMMARY: The mandibular condyle is the rounded protuberance that articulates with the mandibular fossa to form the temporomandibular joint (TMJ). The shape of the mandibular condyle may be classified according to five basic shapes viz. flattened, convex, angled, rounded and concave. Previous research indicated that variation in the shape and size of the mandibular condyle, exists and that population-specific differences may also occur. This study aimed to document the shapes and size of the mandibular condyle and determine their relationship with regard to sex, age and race (if any). The morphometric and morphological parameters of the mandibular condyle were measured and assessed in 54 dry mandible specimens $(n=108)$. The Wedel et al. (1978) classification scheme was adopted in order to document the morphology of the mandibular condyle, utilizing three different aspects. Each of the morphometric and morphological parameters was statistically analyzed using SPSS, to determine if a relationship existed between the afore-mentioned parameters and sex, age and race in each specimen. In the anterior view, the most prevalent shape of the mandibular condyle was the plane/slightly convex shape $(62.0 \%)$, while the round/oval shape was most prevalent in the superior view (56.5\%), with the plane/slightly convex shape being most prevalent in the lateral view $(69.4 \%)$. All morphometric parameters of the mandibular condyle were greater in male than females, which correlated with previous studies. When both sides were compared, statistically significant different relationships were recorded only between: i) sex and the right mandibular condyle in the superior and lateral views; ii) between age and the right mandibular condyle in the superior view. In addition, all morphometric and morphological parameters recorded in this study displayed a statistically significant relationship with race. Knowledge of the anatomy of the mandibular condyle may aid in clinical and surgical procedures, viz. TMJ disorders and mandibular condyle fractures, as well as in the design of population-specific condylar prostheses.

KEY WORDS: Mandibular condyle; Mandibles; Osteology; Morphometry; Morphology.

\section{INTRODUCTION}

The mandibular condyle refers to the rounded protuberance on the back of the mandible that varies significantly both in shape and size (Standring, 2009). Furthermore, Standring documented that the medial side of the mandibular condyle is wider than the lateral side. It articulates with the mandibular fossa of the temporal bone, forming part of the mandibular joint or temporomandibular joint (Segen, 2012). The relationship between the condyle and the mandibular fossa of the temporal bone affect the occlusal properties of the mandible (Wangai et al., 2012; Hedge et al., 2013). The articular head of the condyle joins the ramus through the neck of the mandibular condyle, which is a thin bony projection (Standring). The condyle consists of cancellous bone covered by a thin layer of compact bone and the intra-articular surface is covered by a fibro-cartilage layer (Standring).
The morphological and morphometric features of the mandibular condyles affect the functional activity of the temporomandibular joint (TMJ) (Wangai et al.). Furthermore, Standring stated that the mandibular condyle is the most common site of a mandibular fracture. Subsequently, condylar prosthesis is frequently used to rectify traumatic injuries and in surgical procedures related to disarticulation that may be caused by tumours, congenital malformations and degenerative diseases (Wangai et al.). Furthermore, Hinton (1983) stated that population-specific standards in the morphometry of the mandible exist. However, the literature search revealed that there is a paucity of literature regarding the morphological and morphometric analysis of the mandibular condyle in individuals of African origin.

\footnotetext{
* Department of Clinical Anatomy, School of Laboratory Medicine and Medical Sciences College of Health Sciences, University of KwaZulu-Natal, Durban, South Africa.
} 
Therefore, the purpose of this study was to determine the different shapes of the mandibular condyles and determine their relationship to sex, age and race, if any.

\section{MATERIAL AND METHOD}

This study examined 54 dry mandibles $(n=108$ sides). The dry mandibles were obtained randomly from the bone bank in the Department of Clinical Anatomy, the School of Laboratory Medicine and Medical Sciences, at the University of KwaZulu-Natal. The age, sex and race of the mandibles were obtained from the departmental records. Ethical clearance was obtained (BE: 214/15). All mandibles that showed no pathological changes and damage were included in this study while, mandibles that were eroded, broken and deformed were excluded.

The morphometric parameters and morphological observations of the mandibular condyle were conducted with the use of a digital caliper (Mitutoyo Digimatic Vernier Caliper, Model No. CD-8"C). The results were photographed using a Samsung digital camera (C650) and captured on a Microsoft excel data sheet.

Morphological parameters. The morphology of the condyle was based on three different aspects, viz. anterior; lateral; superior, according to the classification of Wedel et al. (1978) (Table I).

Morphometric parameters. The following measurements were adapted from Matsumoto \& Bolognese (1995) and were undertaken using a Vernier Caliper:

A) Anteroposterior condyle length: the distance between the most prominent points on the anterior and posterior surfaces of the mandibular condyle (Fig. 1).

B) Mediolateral condyle width: the distance between the most prominent medial and lateral points of the mandibular condyle (Fig. 1).

Statistical Analysis. The collected data was captured and analysed using the Statistical Package for Social Sciences (SPSS version 23.0). The Pearson Chi-Square test and Independent sample T-test was used to analyse the relationship between age, sex, race and the morphological and morphometric parameters of the mandibular condyle. A $95 \%$ confidence level was adhered to for all statistical tests. A p-value of less than 0.05 was considered to be statistically significant.
Intra and Inter observer reliability. An examiner assessed the shape of the mandibular condyle and the morphometric parameters on three separate occasions. A second examiner assessed every 10th dry mandible specimen using the same methodology. The student t-test was then employed to compare the two sets of data.

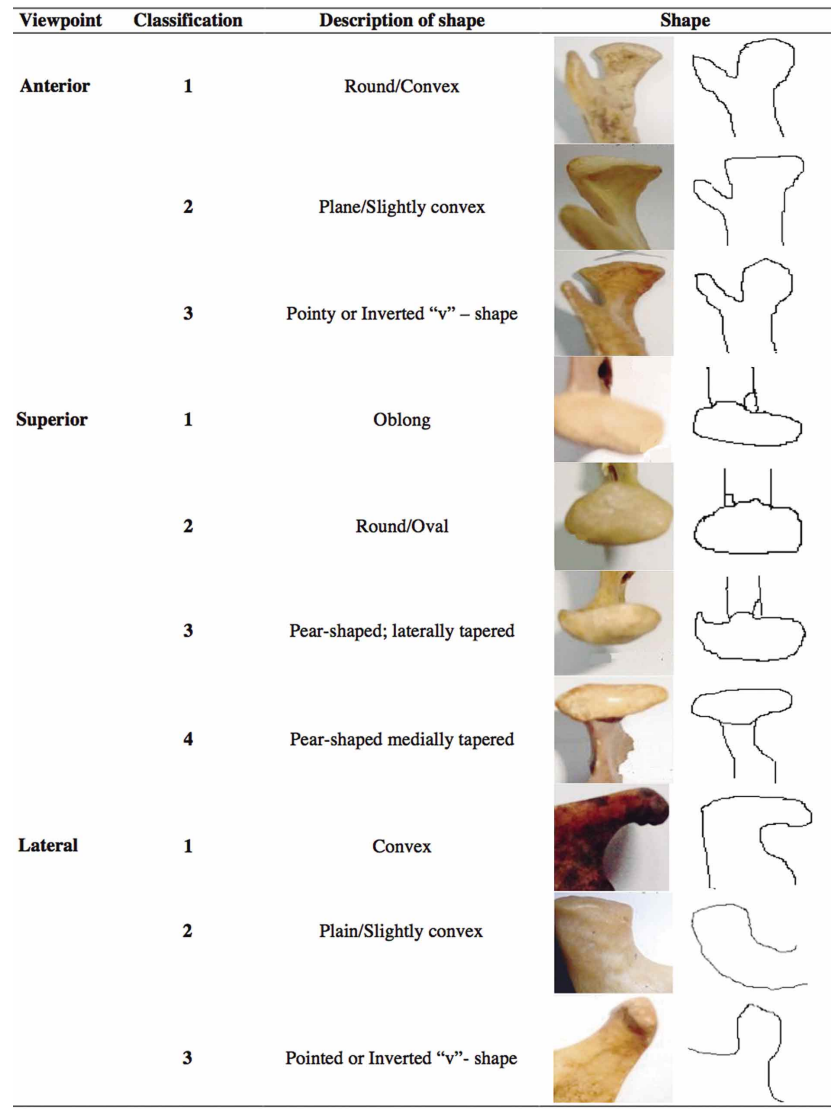

Table I. Wedel's classification scheme for the morphology of mandibular condyles (Adapted from Wangai et al., 2012).

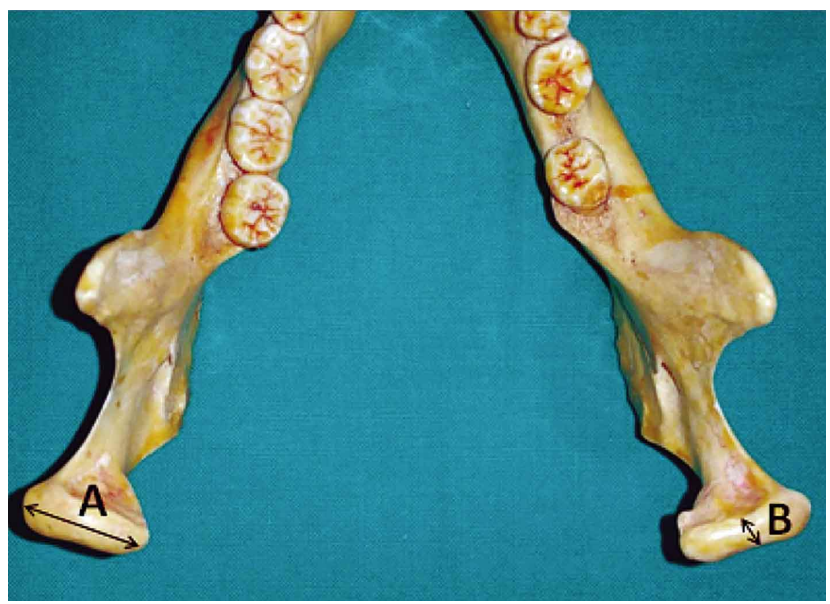

Fig. 1. Measurement of the mandibular condyle carried out on dry bone specimens. 


\section{RESULTS}

\section{Morphology of the mandibular condyle}

1. Anterior view: The plane shaped mandibular condyle was most prevalent [67/108; 62.0\%] (Table II), followed by the round/convex shape $[34 / 108 ; 31.5 \%]$, with the least prevalent being the pointed shaped mandibular condyle [7/ $108 ; 6.5 \%$ ] (Table III). With regards to sex, the plane shaped mandibular condyle was most prevalent, with an incidence of $68.8 \%$ [44/64] and 52.3\% [23/44] in males and females, respectively (Table III). Despite the difference in incidence between males and females regarding the shape of the mandibular condyle, only a statistically significant relationship between race and the anterior view of the mandibular condyle was recorded $(p-v a l u e=0.000)($ Table IV).

2. Superior view: In the superior view, the oval shaped mandibular condyle was most frequently noted $[61 / 108 ; 56.5$ $\%$ ] (Table II), followed by the oblong shape [30/108; 27.8 $\%]$ and pear shape medially tapered [17/108; $15.7 \%]$, respectively (Table V). The oval shaped mandibular condyle was most prevalent in both males and females, with an incidence of $68.8 \%$ [36/64] and 52.3\% [25/44], respectively

\begin{tabular}{lccc}
\hline Viewpoint & Classification and Description & Shape & Percentage \\
\hline Anterior & 2: Plane/slightly convex & & \\
& & & \\
2: Round/oval & & \\
Superior & & & \\
& & & \\
2: Plane/slightly & & \\
& & & \\
& & & \\
\hline
\end{tabular}

Table II. Most prevalent shapes observed in this study in the different viewpoints.

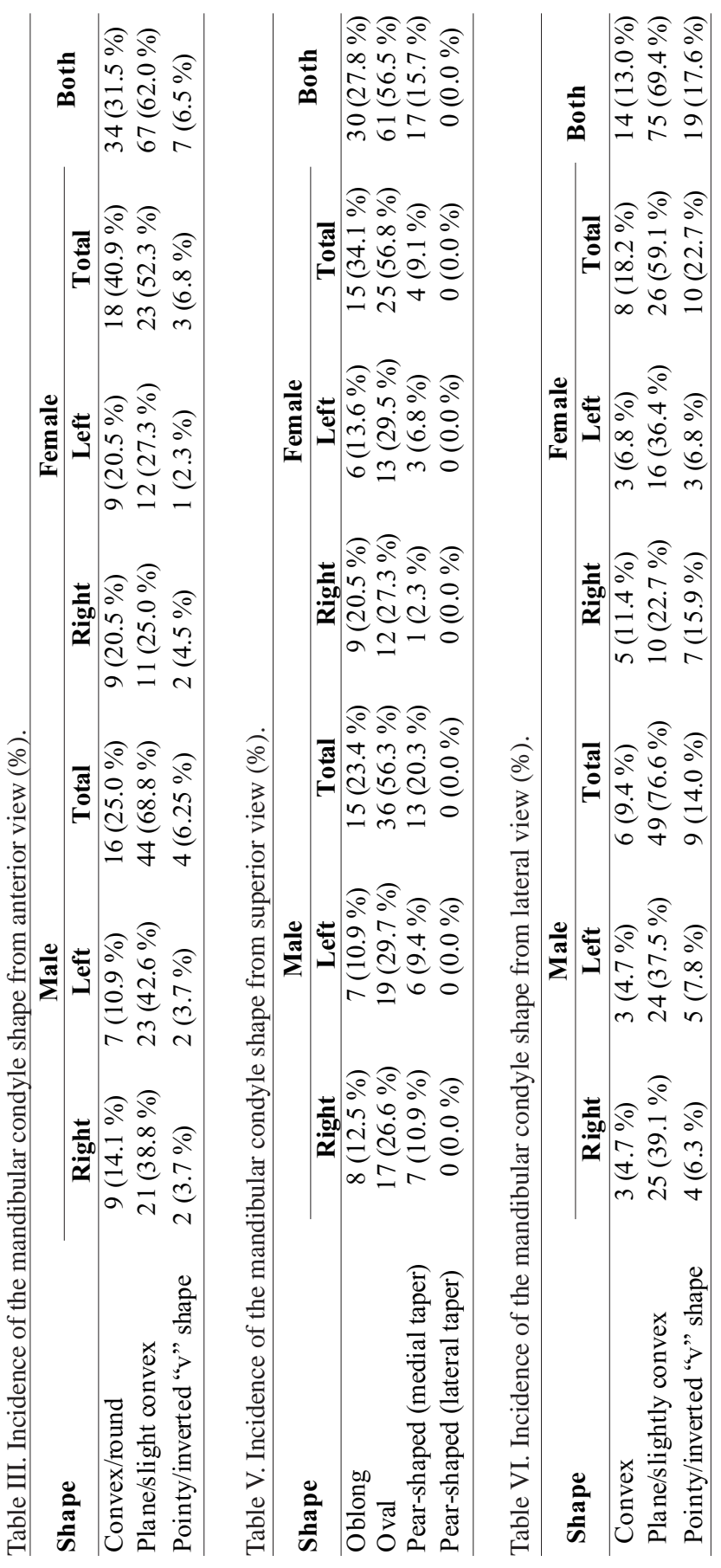

Table IV. P-values for the morphometric and morphological parameters.

\begin{tabular}{lcccccc}
\hline \multirow{2}{*}{ Parameter } & \multicolumn{2}{c}{ Sex } & \multicolumn{2}{c}{$\begin{array}{c}\text { Avalue } \\
\text { Age }\end{array}$} & \multicolumn{2}{c}{ Race } \\
\cline { 2 - 7 } & Right & Left & Right & Left & Right & Left \\
\hline Shape - Anterior view & 0.183 & 0.083 & 0.178 & 0.190 & 0.000 & 0.000 \\
Shape - Superior view & 0.031 & 0.505 & 0.034 & 0.267 & 0.000 & 0.000 \\
Shape - Lateral view & 0.007 & 0.865 & 0.0891 & 0.138 & 0.000 & 0.000 \\
Anter-posterior length & 0.920 & 0.416 & 0.273 & 0.165 & 0.000 & 0.000 \\
Medio-lateral width & 0.444 & 0.076 & 0.847 & 0.315 & 0.000 & 0.000 \\
\hline
\end{tabular}


(Table V). A statistically significant relationship with age and sex was recorded for the shape of right mandibular condyle in the superior view (p-values $=0.031$ and 0.034 , respectively) (Table IV). While, both sides of the mandibular condyle in the superior view displayed a statistically significant relationship with race $(\mathrm{p}$-value $=0.000)($ Table IV $)$.

3. Lateral view: The plane shaped mandibular condyle was most common in both males and females, with a joint prevalence of $69.4 \%$ [75/108] (Table II). This was followed by the pointy [19/108; 17.6\%] and convex shape [14/108; $13.0 \%]$, respectively (Table VI). With regards to sex, the plane shape was more frequently noted in males [49/64; $76.6 \%$ ] than females [26/44; $69.4 \%$ ] (Table VI). In the lateral view, a statistically significant relationship between the right mandibular condyle and sex was recorded $(p$-value $=0.007)($ Table IV), while both, the right and left sides displayed a statistically significant relationship with race $(\mathrm{p}$-value $=0.000)($ Table IV $)$.

Morphometry of the mandibular condyle. Both morphometric parameters recorded were greater in males than females (Table VII). The antero-posterior length of the male mandibular condyle was recorded to be $9.23 \mathrm{~mm}$ and $9.57 \mathrm{~mm}$ on the right and left side, respectively, while in females it was noted to be smaller, with a length of $8.73 \mathrm{~mm}$ and $8.66 \mathrm{~mm}$ on the right and left side, respectively (Table VII). The medio-lateral width on the right side was found to be 18.10 $\mathrm{mm}$ in males and $17.66 \mathrm{~mm}$ in females, while on the left side a width of $18.11 \mathrm{~mm}$ and $17.81 \mathrm{~mm}$ was recorded in males and females, respectively (Table VII). Both parameters recorded statistically significant relationships with race $(\mathrm{p}$-value $=0.000)($ Table IV).

Intra and Inter observer reliability. No statistically significant difference was yielded between these two sets of data ( $p$-value $>0.05$ ).

\section{DISCUSSION}

From the anterior view, the most prevalent shaped mandibular condyle was the plane/slight convex shape in $62.0 \%$ of the sample (Table VIII). These results correlated with previous studies conducted by Matsumoto \& Bolognese and Wangai et al., who reported a $58.4 \%$ and $71.4 \%$ prevalence in the Brazilian and Kenyan populations, respectively (Table VIII). Contradictory to these findings, Yale et al. (1966); Wedel et al. and Magnusson et al. (2008) found the rounded/ convex shaped mandibular condyle to be most common, with incidences of $61.0 \%, 51.0 \%$ and $50.0 \%$, respectively (Table VIII). Only race displayed a statistically significant relationship between the shape of the mandibular condyle in the anterior view $(\mathrm{p}$-value $=0.000$ ).

Table VII. Mean morphometry of the mandibular condyle (mm).

\begin{tabular}{lcccccc}
\hline \multirow{2}{*}{ Parameter } & \multicolumn{2}{c}{ Male } & \multicolumn{2}{c}{ Female } & \multicolumn{2}{c}{ Both } \\
\cline { 2 - 7 } & Right & Left & Right & Left & Right & Left \\
\hline Antero-posterior & 9.23 & 9.57 & 8.73 & 8.66 & 9.08 & 9.20 \\
Medio-lateral & 18.10 & 18.1 & 17.66 & 17.8 & 17.92 & 17.99 \\
\hline
\end{tabular}

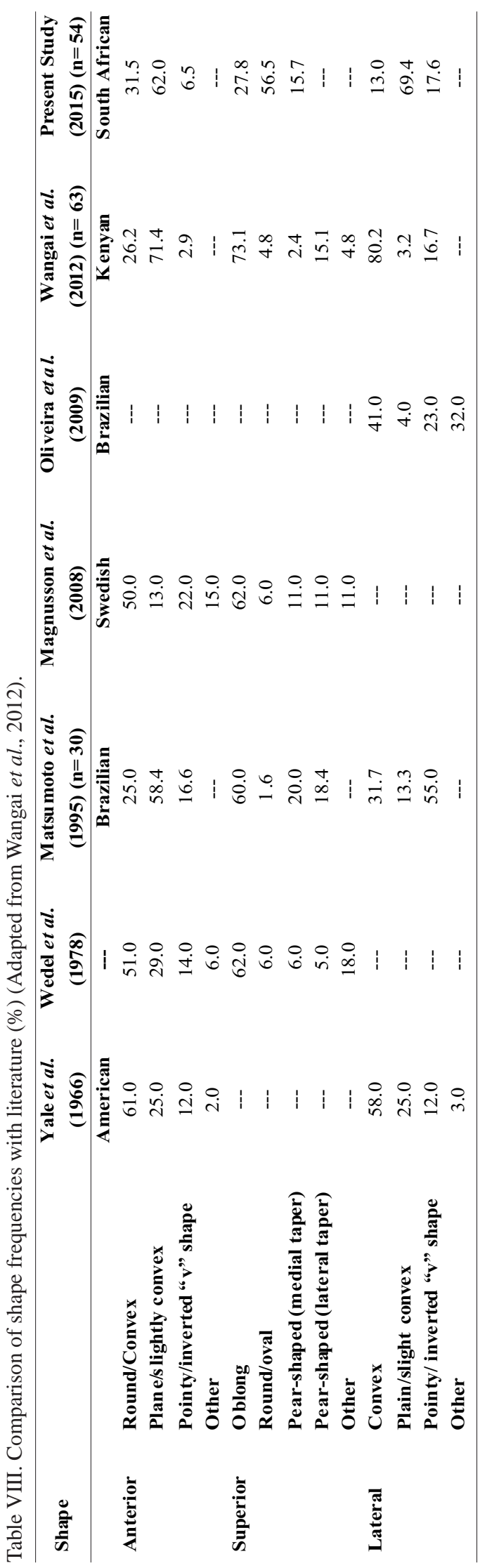


In the present study, the most common shaped condyle from a superior view was the round/oval shaped process in $56.5 \%$ of the sample. However, this result differed from that reported in the literature as previous studies found the oblong shaped condyle to be most prevalent (Wedel et al.; Matsumoto \& Bolognese; Magnusson et al.; Wangai et al.) (Table VIII). A statistically significant relationship with age and sex was recorded for the shape of the right mandibular condyle in the superior view ( $p$-values $=0.031$ and 0.034 , respectively), and for the race on both sides of the mandibular condyle ( $\mathrm{p}$-value= $0.000)$.

In the lateral view, the most prevalent shape was the plane/slightly convex shaped mandibular condyle, with an incidence of $69.4 \%$. However, studies conducted by Yale et al., Oliveira-Santos et al. (2009) and Wangai et al. reported that the convex shape was the most prevalent, while Matsumoto \& Bolognese found that the pointy/ inverted " $\mathrm{v}$ " shape was most common in $55.0 \%$ of their sample (Table VIII). These variations may suggest that population-specific differences exist in the shape of the mandibular condyle. A statistically significant relationship between the right mandibular condyle and sex was recorded $(\mathrm{p}$-value $=0.007)$, while race displayed a statistically significant relationship on both sides of the mandibular condyle $(p$-value $=0.000)$.

With regards to the morphometry, both parameters were recorded to be greater in males than females. The present study recorded that antero-posterior length of the male mandibular condyle as $9.23 \mathrm{~mm}$ and $9.57 \mathrm{~mm}$ on the right and left side, respectively, while in females a mean length of $8.73 \mathrm{~mm}$ and $8.66 \mathrm{~mm}$ on the right and left side was recorded, respectively. These results correlated with Matsumoto \& Bolognese, who reported that the anteroposterior length of the mandibular condyle in the Brazilian population was greater in males than females, with a mean length of $8.42 \mathrm{~mm}$ and $8.25 \mathrm{~mm}$, respectively. A statistically significant relationship between the antero-posterior length and race was recorded on both sides of the mandible (pvalue $=0.000$ ).

In this study, the medio-lateral width in males was reported to be $18.10 \mathrm{~mm}$ and $18.11 \mathrm{~mm}$ on the right and left side, respectively. While in females, the medio-lateral width was recorded to be smaller with a mean width of $17.66 \mathrm{~mm}$ on the right and $17.81 \mathrm{~mm}$ on the left. Similarly, Matsumoto \& Bolognese found that medio-lateral width of the mandibular condyle was greater in males $(18.98 \mathrm{~mm})$ than females $(18.92 \mathrm{~mm})$. A statistically significant relationship between the medio-lateral width and race was recorded on both mandibular condyles ( $\mathrm{p}$-value $=0.000$ ).
Fractures of the mandibular condyle affect mandibular function in different ways: for instance, the function of the mandible will be different if there are unique fractures that are a result of maxillofacial injuries as compared to other traumatic injuries. As a consequence of condylar positional changes, there may be functional derangement affecting occlusion, mastication, airways and speech (Miloro \& Peterson, 2012). Mandibular condyle prostheses are utilized frequently to correct traumatic injury or in operative procedures needing resection with disarticulation, viz. trauma, degenerative diseases, tumours and congenital malformations. Therefore, knowledge of the morphology and morphometry of the mandibular condyle is essential in mandibular condyle prosthesis, since accuracy in the afore-mentioned parameters ensures normal functioning of the TMJ (Wangai et al.).

\section{CONCLUSION}

In the anterior view, the most prevalent shape of the mandibular condyle was the plane/slightly convex shape, which concurred with literature. However, this study displayed unique findings, as the round/oval shape was most prevalent in the superior view and the plane/slightly convex shape in the lateral view. All morphometric parameters of the mandibular condyle were greater in males than females, however these measurements differed from Brazilian population. With regards to sex, only the right mandibular condyle in the superior and lateral view displayed a statistically significant relationship. While, only the right mandibular condyle in the superior view and age recorded a statistically significant relationship. In addition, all morphometric and morphological parameters recorded in this study displayed a statistically significant relationship with race. Knowledge of the anatomy of the mandibular condyle may aid in clinical and surgical procedures, viz. TMJ disorders and mandibular condyle fractures, as well as in the design of population-specific condylar prostheses and in the identification of unknown remains.

ISHWARKUMAR, S.; PILLAY, P.; DEGAMA, B. Z. \& SATYAPAL, K. S. Una evaluación osteometrica del cóndilo mandibular en una población negra KwaZulu-Natal. Int. J. Morphol., 34(3):848-853, 2016.

RESUMEN: El cóndilo del proceso condilar es la protuberancia redondeada que se articula con la fosa mandibular para formar la articulación temporomandibular (ATM). La forma del cóndilo mandibular (CM) se puede clasificar de acuerdo a cinco formas básicas: aplanada, convexa, en ángulo, redondeada y cóncava. Investigaciones anteriores indican que existe variación en 
la forma y tamaño del CM, y también podrían observarce diferencias específicas en la población. El objetivo fue documentar las formas y tamaños del CM, y determinar su relación con respecto al sexo, edad y raza (si los hay). Los parámetros morfométricos y morfológicos del CM se midieron y evaluaron en 54 especímenes de mandíbula secos $(\mathrm{n}=108)$. Se adoptó el sistema de clasificación de Wedel et al. (1978) con el fin de documentar la morfología del CM, utilizando tres aspectos diferentes. Cada uno de los parámetros morfométricos y morfológicos se analizó estadísticamente con el programa SPSS, para determinar si existía una relación entre los parámetros antes mencionados y el sexo, edad y raza de cada especimen. La forma más frecuente del CM fue la plana/ligeramente convexa $(62,0 \%)$ desde una vista anterior, mientras que la redondeada/óvalada fue más prevalente en la vista superior, $(56,5 \%)$, con la forma plana/ ligeramenta convexa más prevalente en la vista lateral $(69,4 \%)$. Todos los parámetros morfométricos del CM fueron mayores en los hombres, y se correlacionaban con estudios anteriores. Cuando se compararon ambas partes, se registraron relaciones estadísticamente significativas diferentes sólo entre: i) el sexo y el CM derecho en las vistas superior y lateral; ii) entre la edad y el CM derecho en la vista superior. Además, todos los parámetros morfométricos y morfológicos registrados en este estudio muestran una relación significativa con la raza. El conocimiento de la anatomía del CM puede ayudar en los procedimientos clínicos y quirúrgicos, en los trastornos de la ATM y las fracturas de CM, así como en el diseño de prótesis condilar específica para la población.

PALABRAS CLAVE: Cóndilo mandibular; Mandíbula; Osteología; Morfometría; Morfología.

\section{REFERENCES}

Hedge, S.; Praveen, B. N. \& Shetty, S. R. Morphological and radiological variations of mandibular condyles in health and diseases: A systematic review. Dentistry, 3(1):154, 2013.

Hinton, R. J. Relationships between mandibular joint size and craniofacial size in human groups. Arch. Oral Biol., 28(1):3743, 1983.

Magnusson, C.; Ernberg, M. \& Magnusson, T. A description of a contemporary human skull material in respect of age, gender, temporomandibular joint changes, and some dental variables. Swed. Dent. J., 32(2):69-81, 2008.

Matsumoto, M. A. \& Bolognese, A. M. Bone morphology of the temporomandibular joint and its relation to dental occlusion. Braz. Dent. J., 6(2):115-22, 1995.

Miloro, M. \& Peterson, L. J. Peterson's Principles of Oral and Maxillofacial Surgery. Shelton, People's Medical Pub. House, 2012. pp.97-103.
Oliveira-Santos, C.; Tarnoschi Bernardo, R. \& Alvarez Capelozza, A. L. Mandibular condyle morphology on panoramic radiographs of asymptomatic temporomandibular joints. Int. J. Dent., 8(3):114-8, 2009.

Segen, J. C. Segen's Medical Dictionary. Huntingdon Valley, Farlex, 2012.

Standring, S. Gray's anatomy. 40 ${ }^{\text {th }}$ ed. Edinburg, Elsevier Churchill Livingstone, 2009.

Wangai, L.; Mandela, P.; Butt, F. \& Ongeti, K. Morphology of the mandibular condyle in a Kenyan population. Anat. J. Afr., 2(1):70-9, 2012

Wedel, A.; Carlsson, G. E. \& Sagne, S. Temporomandibular joint morphology in a medieval skull material. Swed. Dent. J., 2(6):177-87, 1978.

Yale, S. H.; Allison, B. D. \& Hauptfuehrer, J. D. An epidemiological assessment of mandibular condyle morphology. Oral Surg. Oral Med. Oral Pathol., 21(2):169-77, 1996.

\author{
Correspondence to: \\ Professor K. S. Satyapal \\ Department of Clinical Anatomy \\ School of Laboratory Medicine and Medical Sciences \\ College of Health Sciences \\ University of KwaZulu-Natal \\ Private Bag X54001 \\ Durban, 4000 \\ SOUTH AFRICA
}

Email: satyapalk@ukzn.ac.za

Received: 01-03-2016

Accepted: 22-06-2016 